\title{
Neuroglobin Plays a Protective Role in Arsenite-Induced Cytotoxicity by Inhibition of Cdc42 and Rac1GTPases in Rat Cerebellar Granule Neurons
}

\author{
Xiaona Liu Yanhui Gao Yuan An Xiaoyan Fu Yuanyuan Li Dianjun Sun \\ Jing Wang
}

Center for Endemic Disease Control, Chinese Center for Disease Control and Prevention, Harbin Medical University, Key Lab of Etiology and Epidemiology, Education Bureau of Heilongjiang Province \& Ministry of Health, Harbin, China

\section{Key Words}

Sodium Arsenite • Neuroglobin • Rat Cerebellar Granule Neurons • Cytotoxicity • Rac1 GTPase - Cdc42 GTPase

\begin{abstract}
Background and Aims: We have previously shown that neuroglobin (Ngb) expression can be regulated by sodium arsenite $\left(\mathrm{NaAsO}_{2}\right)$ exposure in rat cerebellar granule neurons (CGNs). However, the precise molecular mechanisms of $\mathrm{Ngb}$ action are largely unknown. Ras homolog (Rho) guanosine triphosphatases (Rho GTPases) are involved in the regulation of a number of cellular processes, including cell cytotoxicity. It has been reported that $\mathrm{Ngb}$ can act as a guanine nucleotide dissociation inhibitior (GDI) role to inactivate Rho GTPases. Therefore, we investigated Rho GTPases activation induced by $\mathrm{NaAsO}_{2}$ exposure in rat CGNs and effects of Rho GTPases activation on the cells. We also investigated the role of $\mathrm{Ngb}$ in this process. Methods: Primary cultures of CGNs were prepared from 7-day-old Wistar rat pups. The cytotoxic effects of $\mathrm{NaAsO}_{2}$ on CGNs were evaluated using the Cell Counting Kit-8 assay and TUNEL staining. RNA interference technology was used to silence $\mathrm{Ngb}$, and the subsequent effects were evaluated by quantitative RT-PCR and Western blot. Cdc42 and Rac1 activation were measured by pull-down assay and Western blot. Results: $\mathrm{NaAsO}_{2}$ induced cytotoxicity in rat CGNs, increased GTP-bound form of Cdc42 and Rac1 GTPases in the cells. Furthermore, inhibition of Cdc42 or Rac1 activity using the inhibitor ZCL278 or NSC23766 decreased apoptosis and increased cell viability in the cells exposed to $\mathrm{NaAsO}_{2}$. Using siRNA-mediated knockdown, we show that $\mathrm{NaAsO}_{2}$-induced cytotoxicity was exacerbated, activation of $\mathrm{Cdc} 42$ (GTP-Cdc42) and Rac1 (GTP-Rac1) was increased in Ngb RNA silencing cells. Conclusions: cytotoxic effects of $\mathrm{NaAsO}_{2}$ on rat CGNs is induced at least partly by Cdc42 and Rac1 activation, and $\mathrm{Ngb}$ can inhibit Cdc42 and Rac1 activation to play protective role in rat CGNs exposed to $\mathrm{NaAsO}_{2}$.

Copyright (C) 2015 S. Karger AG, Basel

D. Sun and J. Wang contributed equally to the work and should be considered as co-corresponding authors Dr. Dianjun Sun, Center for Endemic Disease Control, Chinese Center for Disease Control and Dr. Jing Wang




\section{Introduction}

Arsenic (As) is a widespread toxicant found in water, food, and air. Chronic As toxicity is a growing public health problem that affects more than 30 million people worldwide, and China is one of the most severely affected countries. Inorganic As, the predominant form identified in drinking water, is more toxic than the organic forms. Arsenite [ $\operatorname{As}(\mathrm{III})]$, the trivalent state of inorganic As, is able to bind to macromolecular thiols and is more toxic than the pentavalent from (arsenate, As V) [1, 2]. Long-term health effects of inorganic As in drinking water may result in neurological abnormalities [3]. Nervous system damage due to As exposure has been wildly studied and several studies have shown that people consuming water contaminated with high-level As particularly experience cerebellar symptoms [4-6]. Our previous study has demonstrated that rat cerebellum is one of the critical target organs of inorganic arsenite exposure $[7,8]$. The involved mechanism research of As toxic effects on cerebellum is of importance.

It has been widely reported that arsenite results in cytotoxicity and mitogen-activated protein kinases (MAPKs) activation $[9,10]$. Cdc42 and Rac1, the most extensively studied members of Ras homolog (Rho) guanosine triphosphatases (GTPases), are upstream signals of MAPKs [11, 12]. In mammals, the Rho GTPase family consists of 5 subfamilies, Rho, Rac, Cdc42, Rnd, and Rho BTB, based on their sequence identity, domain structure, and function[13]. Each of Rho GTPases is an important regulator of many biological processes including cytoskeletal reorganization, membrane trafficking, cell cycle progression, and transcription [14-16]. As a molecular switch, Rho family GTPases alternate between an inactive GDP-bound and an active GTP-bound state $[17,18]$. The activation status of Rho family GTPases is supported by three regulatory proteins: Guanine nucleotide exchange factors (GEFs), GTPase activations proteins (GAPs), and guanine nucleotide dissociation inhibitors (GDIs). GEFs facilitate the exchange of GDP for GTP, whereas GAPs promote the hydrolysis of GTP to GDP. GDI proteins exerts additional negative regulation and thus keep Rho GTPases from being activated [19]. It has been reported that activated Rho-like GTPase Cdc42 can induce apoptosis of neurons, whereas expression of dominant negative mutants of Cdc42 blocked apoptosis [20]. Also, one study has shown that injured axon can regrow on complex inhibitor substrates when Rho GTPases are inactivated [21]. All mentioned above support the fact that inhibition of Rho GTPases can play a protective role in these biological processes.

Neuroglobin ( $\mathrm{Ngb}$ ), discovered in 2000, is widely expressed in vertebrate's central and peripheral nervous systems [22]. Accumulating evidence has clearly demonstrated that Ngb is an endogenous molecule that exhibits neuroprotective role against hypoxic/ischemic injuries in vivo and in vitro [23-25]. Furthermore, several reports have shown that Ngb can act as a signal transducer and exert GDI role inhibiting the rate of exchange of GDP for GTP, thus playing against neuronal injuries [26-28]. We have previously demonstrated neuroglobin (Ngb) expression can be regulated by $\mathrm{NaAsO}_{2}$ exposure in rat cerebellar granule neurons (CGNs) [29]. We speculate Ngb may be an important regulator in the toxic process of $\mathrm{NaAsO}_{2}$ exposure.

In this study, we set out to determine the specific role of $\mathrm{Ngb}$ in the $\mathrm{NaAsO}_{2}$-induced neurotoxicity and Rho GTPases activation in rat CGNs. Our data suggest Ngb can inhibit RhoGTPases activation to play protective role in rat CGNs exposed to $\mathrm{NaAsO}_{2}$.

\section{Materials and Methods}

Chemicals and Reagents

NeurobasalA and B27 supplement were purchased from Gibco (Grand Island, NY, USA). Fetal bovine serum (FBS) and DMEM/F12 were from Hyclone Laboratories (Logan, UT, USA). Poly-L-lysine hydrobromide, Cytosine arabinoside and DNase I were purchased from Sigma-Aldrich (St. Louis, MO, USA). Hanks' Balanced Salt Solution (without $\mathrm{CaCl} 2, \mathrm{MgCl} 2$ or $\mathrm{MgSO} 4$ ) and L-glutamine were purchased from Solarbio Science \& 


\section{Cellular Physiology Cell Physiol Biochem 2015;36:1613-1627 \begin{tabular}{ll|l} 
and Biochemistry 10.1159/000430323 & $\begin{array}{l}\text { D 2015 S. Karger AG, Basel } \\
\text { Published online: July 10, } 2015\end{array}$ & \begin{tabular}{l} 
www.karger.com/cpb \\
\cline { 2 - 3 }
\end{tabular} \\
\cline { 2 - 3 }
\end{tabular}}

Technology (shanghai, China). Cell Counting Kit-8 and BCA protein assay kit were from Beyotime Institute of Biotechnology (Shanghai, China). Neuroglobin primary antibody was from abcam (Cambridge, UK). Secondary antibody was from Rockland Immunochemicals Inc. (Gilbertsville, PA, USA). Complete Inhibitor Cocktail and In Situ cell death detection kit were purchased from Roche (Indianapolis, IN, USA). Rac1 inhibitor NSC23766 was purchased from Santa Cruz Biotechnology Inc. (CA, USA). Cdc42 inhibitor ZCL278 was purchased from Selleckchem (Houston, USA). Cdc42 Activation Assay Biochem Kit and Rac1 Activation Assay Biochem Kit were purchased from Cytoskeleton, Inc. (Denver, CO, USA). Lipofectamine RNAiMAX, Ngb siRNA and Opti-MEM were purchased from Life Technologies (Carlsbad, Cal, USA). Trizol reagent and PrimeScript RT reagent Kit was purchased from Takara Bio Inc. (Dalian, China).

\section{Primary Culture of Rat CGNs}

Primary cultures of rat cerebellar granule neurons (CGNs) were prepared from 7-day-old Wistar rat pups (provided by Animal Experimental Center of the Second Affiliated Hospital of Harbin Medical University, China), as described elsewhere [30]. Briefly, cerebella were dissected, meninges were removed, and tissues were digested with $0.5 \%$ trypsin at $37^{\circ} \mathrm{C}$ for $10 \mathrm{~min}$ and treated with $50 \mathrm{mg} / \mathrm{L}$ DNase I at room temperature for $3 \mathrm{~min}$. Cells were dissociated by repeated pipetting, and separated from nondissociated

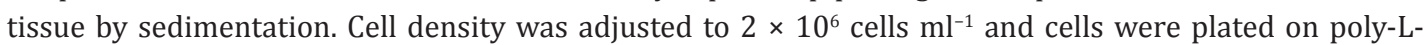
lysine-coated plates at a density of $4 \times 10^{5}$ cells cm$^{-2}$. Cultures were grown in Neurobasal A containing $2 \%$ B27 NeuroMIX supplement, $2 \mathrm{mM}$ L-glutamine, $100 \mathrm{U} / \mathrm{ml}$ penicillin, $0.1 \mathrm{mg} / \mathrm{ml}$ streptomycin. Cytosine arabinoside $(5 \mu \mathrm{M})$ was added in the media $16-18 \mathrm{~h}$ after plating to inhibit the growth of non-neuronal cells.

\section{siRNA Transfection}

The Ngb specific siRNA (Ambion, Life Technologies) was transfected with Lipofectamine RNAiMAX (Life Technologies) in six-well plates. The targetsequence against Ngb wassense $5^{\prime}$-GGACCACAUUAGGAAGGUUtt- ${ }^{\prime}$ and anti-sense 5'-AACCUUCCUAAUGUGGUCCag-3' (NCBI UniGene ID: Rn.64645). The negative control siRNA was used as non-targeting control for all siRNA experiment. Briefly, Lipofectamine RNAiMAX diluted in Opti-MEM $(9 \mu \mathrm{L} / 150 \mu \mathrm{L})$ was incubated for $5 \mathrm{~min}$. Control siRNA and Ngb siRNA (30 pmol) were diluted in Opti-MEM $(150 \mu \mathrm{L})$ and added to the Lipofectamine RNAiMAX mixture. The incubation was continued for an additional $20 \mathrm{~min}$ before addition to cultures and transfection. Following $48 \mathrm{~h}$ transfection, the rat CGNs were treated with $\mathrm{NaAsO}_{2}(0 \mu \mathrm{M}, 10 \mu \mathrm{M})$ for $45 \mathrm{~min}$ or $24 \mathrm{~h}$ and subject to western blotting, Quantitative Real-Time PCR and TUNEL assay.

\section{TUNEL Assay}

We performed the TUNEL assay using an In Situ cell death detection kit (Roche) following the instructions. Briefly, rat CGNs exposed to $\mathrm{NaAsO}_{2}(0 \mu \mathrm{M}, 10 \mu \mathrm{M})$ were grown in 96-well plates for $24 \mathrm{~h}$ with or without $20 \mu \mathrm{M}$ ZCL278 (an inhibitor of Cdc42) pretreatment for $1 \mathrm{~h}, 50 \mu \mathrm{M}$ NSC23766 (an inhibitor of Rac1) pretreatment for $12 \mathrm{~h}$, Ngb-siRNA transfection for $48 \mathrm{~h}$. The cells were washed with PBS for 3 times, fixed with $4 \%$ paraformaldehyde and permeabilized in a solution of $0.1 \%$ Triton X-100 and $0.1 \%$ sodium citrate at a room temperature. Cells were incubated with $50 \mu \mathrm{L}$ TUNEL reaction mixture. Nuclei of both normal and apoptotic cells were stained with $100 \mathrm{nM} \mathrm{4',} \mathrm{6-diamidino-2-phenylindole} \mathrm{dihydrochloride} \mathrm{(DAPI).} \mathrm{TUNEL}$ positive cells were observed using fluorescence microscope (C1-plus, Nikon, Japan). Imagepro plus6.0.0.260 software was used to quantify. The percentage of apoptotic cells was determined in five randomly chosen fields.

\section{Cell Viability Assay}

Viability of rat CGNs was assessed by a CCK-8 [31]. Cells were seeded in 96-well plates at a density of $4 \times 10^{5}$ cells cm${ }^{-2}$. The plates were pre-incubated for $24 \mathrm{~h}$, followed by the treatments of $\mathrm{NaAsO}_{2}(0 \mu \mathrm{M}, 10$ $\mu \mathrm{M})$ for $24 \mathrm{~h}$ with varying concentrations of ZCL278 or $\operatorname{NSC23766~}(0,10,20,50$ and $100 \mu \mathrm{M})$ for $1 \mathrm{~h}$ or $12 \mathrm{~h}$, or with $20 \mu \mathrm{M}$ ZCL278 (an inhibitor of Cdc42) pretreatment for $1 \mathrm{~h}, 50 \mu \mathrm{M}$ NSC23766 (an inhibitor of Rac1) pretreatment for $12 \mathrm{~h}$, Ngb-siRNA transfection for $48 \mathrm{~h}$. Then, $10 \mu \mathrm{L}$ CCK-8 solution was added to each well of the plates and cells were incubated for $4 \mathrm{~h}$ in the incubator $\left(37^{\circ} \mathrm{C}\right.$ and $\left.5 \% \mathrm{CO}_{2}\right)$. The optical density values at a wavelength of $450 \mathrm{~nm}$ were measured on an imaging reader (Cytation3, BioTek, USA). Viability results were expressed as: Cell viability $=\left(A_{\text {experimental }}-A_{\text {blank }}\right) /\left(A_{\text {control }}-A_{\text {blank }}\right) \times 100 \%$. The absorbance measured from non-treated cells was taken to be $100 \%$. 


\section{Cellular Physiology Cell Physiol Biochem 2015;36:1613-1627 \begin{tabular}{ll|l} 
and Biochemistry & $\begin{array}{l}\text { DOI: 10.1159/000430323 } \\
\text { Published online: July 10, } 2015\end{array}$ & $\begin{array}{l}\text { O 2 2015 S. Karger AG, Basel } \\
\text { www.karger.com/cpb }\end{array}$ \\
\cline { 2 - 3 }
\end{tabular}}

\section{Quantitative Real-Time PCR}

Total RNA was extracted from primary-cultured rat CGNs with Trizol Reagent. Reverse-transcription $\left(37^{\circ} \mathrm{C}\right.$ for $15 \mathrm{~min}$ and $85^{\circ} \mathrm{C}$ for $\left.30 \mathrm{~s}\right)$ and the qRT-PCR were performed by using PrimeScript RT reagent Kit according to the manufacturer's instructions. The qRT-PCR for Ngb and the housekeeping gene $\beta$-actin was performed in a total volume of $20 \mu \mathrm{L}$ in each well using $1 \mu \mathrm{L}$ cDNA. Primers were the same as those reported before [32]. The forward primer for rat Ngb was 5'-CCTGGACCACATTAGGAAGG-3' and reverse 5'-TCACCTACTGTCGAGAAGGA-3' (GenBank accession number is NM_033359). The amplification fragment length of Ngb was $150 \mathrm{bp}$; forward primer for rat $\beta$-actin was $5^{\prime}$-TGACGGTCAGGTCATCACTATC- $3^{\prime}$ and reverse 5'-GGCATAGAGGTCTTTACGGATG-3' (Genbank accession number is NM_031144). The amplification fragment length of $\beta$-actin was $247 \mathrm{bp}$. The PCR condition consisted of initial denaturation step of $95{ }^{\circ} \mathrm{C}$ for $30 \mathrm{~s}$, followed by 40 cycles of $95{ }^{\circ} \mathrm{C}$ for $5 \mathrm{~s}, 56^{\circ} \mathrm{C}$ for $15 \mathrm{~s}$ and $72{ }^{\circ} \mathrm{C}$ for $15 \mathrm{~s}$. Extension was at $72{ }^{\circ} \mathrm{C}$ for $60 \mathrm{~s}$. Specificity of amplified products was monitored by performing melting curves at the end of each amplification and finally a cooling step to $30^{\circ} \mathrm{C}$. Melting curves were acquired by stepwise increase of the temperature from $55^{\circ} \mathrm{C}$ to $95^{\circ} \mathrm{C}$. All the amplicons generated a single peak, thus reflecting the specificity of the primers. Experiments were performed on Chromo4 real time PCR detector (Bio-Rad, America). Results were calculated using the Delta Ct method normalizing to $\beta$-actin expression for each sample $[33,34]$.

\section{Western Blot Analysis of Neuroglobin Expression}

Primary cultured cells were washed with cold phosphate-buffered saline (PBS) and extracted in a lysis buffer including RIPA buffer and Complete Mini. The protein concentrations were determined by an enhanced BCA Protein Assay Kit. An equal amount of protein for each sample in loading buffer was heated at $100^{\circ} \mathrm{C}$ for $5 \mathrm{~min}$ and loaded onto $12 \%$ polyacrylamide gels. After electrophoresis, proteins were transferred onto polyvinylidene difluoride membranes. Subsequently, the membrane was blocked by incubating in TBST plus $5 \%$ fat-free milk at room temperature for $2 \mathrm{~h}$ and then was probed with Ngb primary antibody (Mouse monoclonal $\mathrm{mAb}, 1: 1000$ ) overnight a $4{ }^{\circ} \mathrm{C}$. After incubation for $1 \mathrm{~h}$ with the secondary antibody(Anti-Mouse IgG,1:5000), signals were detected by Odyssey Infrared Imaging System (Li-COR, USA). Data are expressed as normalized ratios to GAPDH.

\section{Pull-Down Assay}

Cdc42 and Rac1 were measured using a Cdc42 and Rac1 pull-down kit according to the manufacturer' s protocols, respectively [35, 36]. Briefly, rat CGNs cultures were starved with serum-free medium for 24 hours, then exposed to $\mathrm{NaAsO}_{2}$ before an ice-cold PBS rinse and lysis in $500 \mu \mathrm{L}$ of the lysis buffer including Complete Mini. Cell lysates were clarified by centrifugation at $10,000 \times \mathrm{g}$ for $15 \mathrm{~min}$. The supernatant was collected; equal volumes of supernatant were incubated with PAK-PBD affinity beads for 1 hour at $4{ }^{\circ} \mathrm{C}$, followed by two washes in the supplied wash buffer. Bound proteins were boiled in $5 \times 1 \%$ SDS sample buffer at $95^{\circ} \mathrm{C}$ for 5 minutes and detected by $12 \%$ polyacrylamide gels and Western blot with anti-Cdc42 (Mouse monoclonal mAb,1:250) and Rac1 (Mouse monoclonal mAb,1:500) analysis. Aliquots of total lysate were also analyzed for the amount of Cdc42 and Rac1 present, respectively. Relative Cdc42 and Rac1 activity is the ratio of active Cdc42 and Rac1 divided by total Cdc42 and Rac1 normalized to the untreated control, respectively.

\section{Statistical Analysis}

All experiments were repeated for at least 3 times independently. Results were presented as mean \pm standard deviation and evaluated with one-way-ANOVA followed by Least Significant Difference test. All statistical evaluations were carried out using the SPSS17.0 software package. $P$ values less than 0.05 were considered statistically significant.

\section{Results}

Induction of Neurotoxicity in Rat CGNs by Treatment with $\mathrm{NaAsO}_{2}$

We evaluated the neurotoxic effects, including apoptosis and cell viability, of $\mathrm{NaAsO}_{2}$ on rat CGNs using TUNEL and CCK-8 assays. Apoptosis was detected by TUNEL assay. TUNEL-positive rat CGNs exposed to $\mathrm{NaAsO}_{2}$ were rounder and smaller than the healthy 


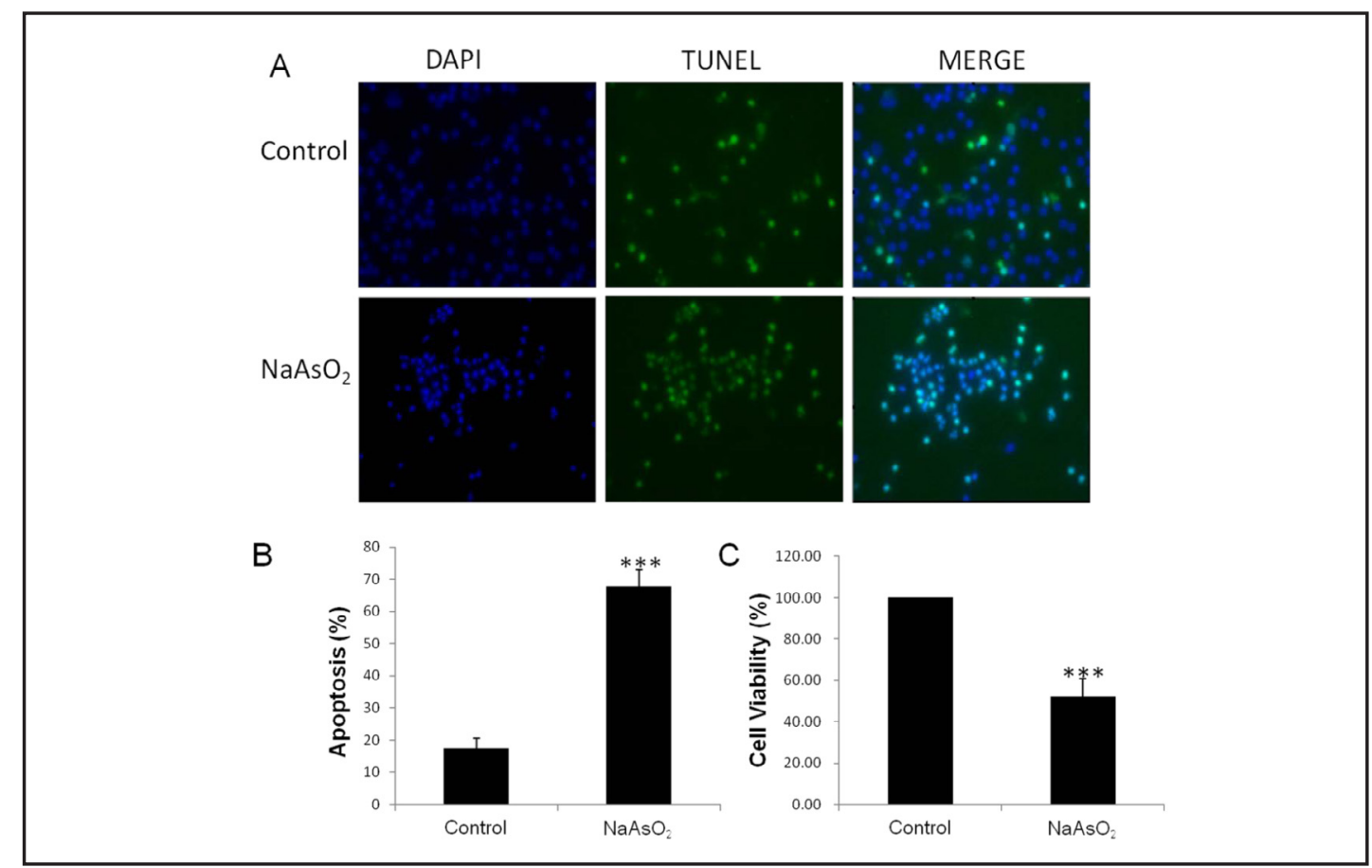

Fig. 1. Detection of apoptotic rat CGNs by TUNEL assay. A. Representative fluorescence images of cells exposed to 0 and $10 \mu \mathrm{M} \mathrm{NaAsO}$ for $24 \mathrm{~h}$. After treatment of $\mathrm{NaAsO}_{2}$, specimens were labeled with TUNEL (green). Nuclei were stained blue with DAPI. Original Magnifications: $\times 400$. B. The graph indicates that TUNEL-positive rat CGNs exposed to $\mathrm{NaAsO}_{2}(10 \mu \mathrm{M})$ increased significantly compared with those of normal cells. Data are expressed as mean \pm SD from at least 5 visual fields. C. Rat CGNs in 96-well plates were treated with $\mathrm{NaAsO}_{2}(0 \mu \mathrm{M}$ and $10 \mu \mathrm{M})$ for $24 \mathrm{~h}$, and cell viability was determined using the CCK-8 assay (10 $\mu \mathrm{L} /$ well CCK-8 solution for $4 \mathrm{~h}$ ). $\mathrm{NaAsO}_{2}$ decreased the viability of CGNs. All statistical results are expressed as means \pm SD from at least three independent experiments. ${ }^{* * *} P<0.001 \mathrm{VS}$ control group.

cells (Fig. 1A). Both rounding-up of the cell and reduction of the cell volume are displayed, typical features of cells undergoing apoptosis [37]. In this case, after treated with 0 and $10 \mu \mathrm{M} \mathrm{NaAsO}$ for $24 \mathrm{~h}$, percentages of TUNEL-positive rat CGNs were $20.61 \pm 6.35 \%$ and $67.77 \pm 5.37 \%$, respectively. Apoptotic cells increased significantly in $10 \mu \mathrm{M}$ exposure groups compared with the control groups $(P<0.001$; Fig. 1B). Furthermore, as shown in Fig. 1C, the CCK-8 assay revealed significantly decreased cell viability in $\mathrm{NaAsO}_{2}$ exposure groups compared with the control group $(p<0.001$; Fig. 1 C). This means that arsenite induced neurotoxicity in rat CGNs.

\section{Activation of Cdc42 and Rac1 GTPases by $\mathrm{NaAsO}_{2}$ Exposure in Rat CGNs}

As there is a growing body of evidence that inorganic As can activate the Rho family of GTPases $[9,38,39]$, we therefore wished to study whether $\mathrm{NaAsO}_{2}$ regulates the activation states of major members of the Rho family, namely Cdc42 and Rac1 in rat CGNs. Rat CGNs were treated with $\mathrm{NaAsO}_{2}$ at a concentration of $10 \mu \mathrm{M}$ for $0,30,60,120,240 \mathrm{~min}$ and the activation of Cdc42 and Rac1 was assessed by pull-down assay and western blot with antiCdc42 and anti-Rac1 antibody analysis. Results (Fig. 2) show that Cdc42 and Rac1 were activated significantly by $\mathrm{NaAsO}_{2}$ exposure. Relative Cdc42 and Rac1 activity is the ratio of active Cdc42 and Rac1 divided by total Cdc42 and Rac1 normalized to the untreated control, respectively. Ratios of active Cdc42 in the five groups are $1.00 \pm 0.14,2.11 \pm 0.21,1.49 \pm 0.26$, $1.23 \pm 0.25,1.03 \pm 0.14$, respectively (Fig. $2 A$ ). Significant increase occurred in 30 and $60 \mathrm{~min}$ $\mathrm{NaAsO}_{2}$ treatment groups compared with the control group ( $p<0.01$ in 60 min group, $p<0.001$ in 30 min group). Ratios of active Rac1 in the five groups are $1.00 \pm 0.26,2.49 \pm 0.58,2.03 \pm 0.70$, $2.05 \pm 0.18,1.45 \pm 0.29$, respectively (Fig. 2B). active Rac1 ratio in the 30,60 and $120 \mathrm{~min}$ 

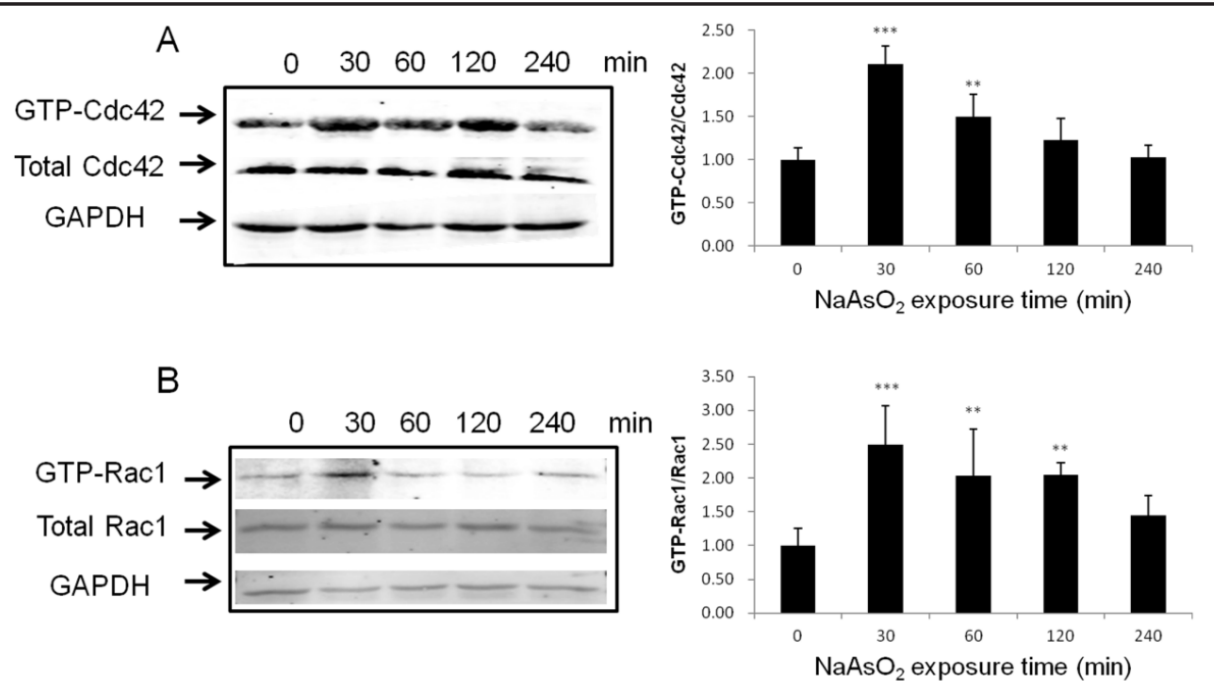

Fig. 2. Treatment with $\mathrm{NaAsO}_{2}$ increased levels of activated Cdc42 and Rac1 in rat CGNs. Representative images of western blots and corresponding densitometric quantification of the level of activated (A) Cdc42 and (B) Rac1 in rat CGNs. Relative Cdc42 and Rac1 activity is the ratio of active Cdc42 and Rac1 divided by total Cdc42 and Rac1 normalized to the untreated control, respectively. All statistical results are expressed as means \pm SD from three independent experiments. ${ }^{* *} P<0.01,{ }^{* * *} P<0.001$ VS control group.

Fig. 3. NSC23766 or ZCL278 ameliorated $\mathrm{NaAsO}_{2}$-induced inviability of rat CGNs in a dose-dependent manner. Rat CGNs in 96-well plates were pretreated with different concentrations of NSC23766 or ZCL278 for $12 \mathrm{~h}$ or 1 h, followed by treatment with $\mathrm{NaAsO}_{2}$ for 24 h. Cell viability was expressed as a percentage of untreated cells. All statistical results are expressed as means \pm SD from three independent experiments. ${ }^{*} P<0.05$ as compared with control group alone, ${ }^{\#} P<0.05$ as compared with $\mathrm{NaAsO}_{2}$ treatment group alone.

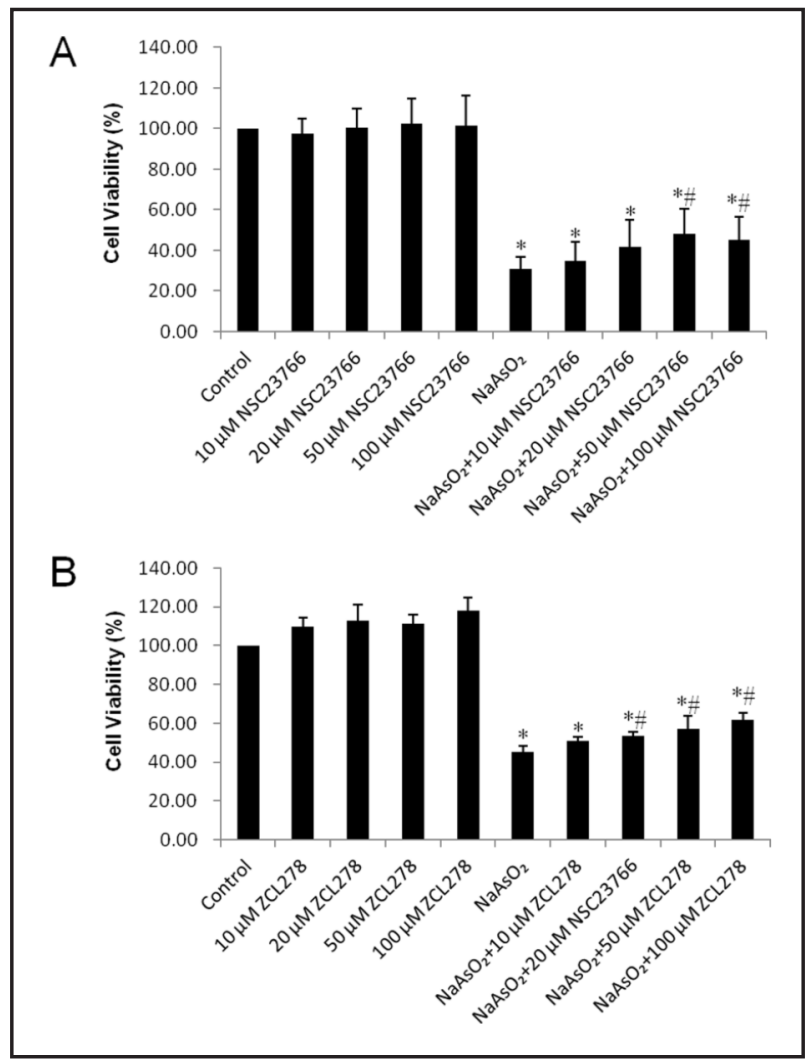

$\mathrm{NaAsO}_{2}$ treatment groups increased significantly compared with the control group ( $\mathrm{p}<0.01$ in 60 and 120 min groups, $\mathrm{p}<0.001$ in 30 min group). This indicates $\mathrm{NaAsO}_{2}$ increased the levels of the active GTP-bound form of Cdc42 and Rac1 in rat CGNs. 


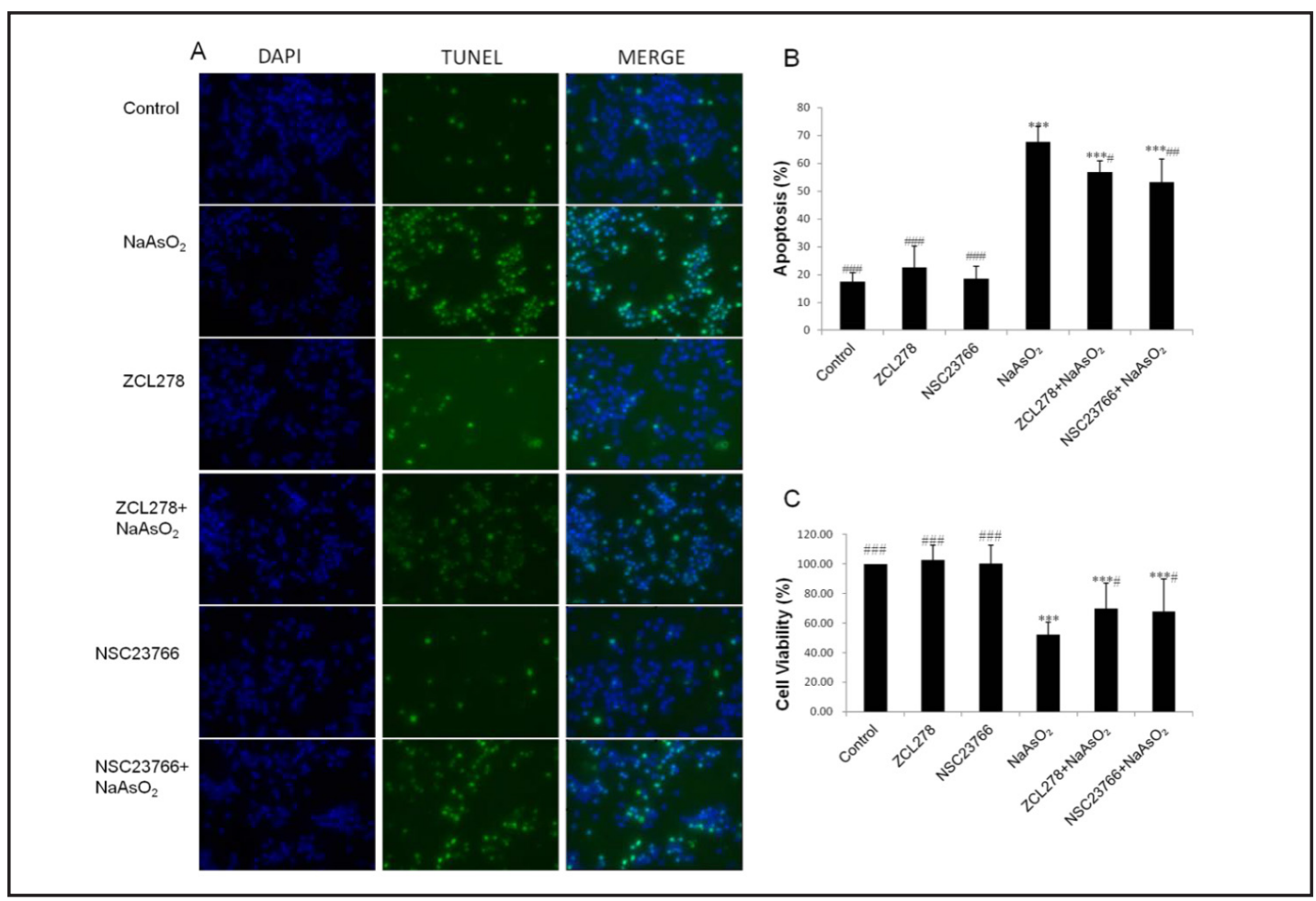

Fig. 4. Rho GTPases were involved in $\mathrm{NaAsO}_{2}$ induced apoptosis in rat CGNs. A. Representative fluorescence images of cells exposed to 0 and $10 \mu \mathrm{M} \mathrm{NaAsO}_{2}$ for $24 \mathrm{~h}$ with or without ZCL278 (an inhibitor of Cdc42), or a Rac1 inhibitor NSC23766. Both ZCL278 and NSC23766 reduced the apoptotic cells. B. The graph indicates TUNEL-positive rat CGNs exposed to $\mathrm{NaAsO}_{2}(10 \mu \mathrm{M})$ with ZCL278 or NSC23766 groups decreased significantly compared with those of $\mathrm{NaAsO}_{2}$ treatment group. Data are expressed as mean \pm SD from at least 5 visual fields. C. Rat CGNs in 96-well plates were treated by 0 and $10 \mu \mathrm{M} \mathrm{NaAsO}$ for $24 \mathrm{~h}$ with or without ZCL278 (an inhibitor of Cdc42) pretreatment for $1 \mathrm{~h}$, or a Rac1 inhibitor NSC23766 pretreatment for $12 \mathrm{~h}$, and assessed by a CCK-8. ZCL278 and NSC23766 increased rat CGNs viability exposed to $\mathrm{NaAsO}_{2}$. All statistical results are expressed as means \pm SD from at least three independent experiments. ${ }^{* * *} P<0.001$ vs control, " $P<0.05$, "\# $P<0.01$, "\#\# $P<0.001$ VS NaAsO 2 treatment group.

Effects of different concentrations of ZCL278 or NSC23766 on viability of rat CGNs exposed to $\mathrm{NaAsO}_{2}$

In this report, we examined the effect of NSC23766 or ZCL278 on the viability of rat

CGNs exposed by $\mathrm{NaAsO}_{2}$. Concentration-dependent viability was clearly observed when rat CGNs were incubated with increasing concentrations of NSC23766 or ZCL278 in $\mathrm{NaAsO}_{2}$ treatment groups (Fig. 3) in this study. The viability of $\mathrm{NaAsO}_{2}$ exposure rat CGNs increased significantly with 20, 50 and $100 \mu \mathrm{M}$ ZCL278 pretreatment for $1 \mathrm{~h}(p<0.05)$, when compared with $\mathrm{NaAsO}_{2}$ treatment group alone. NSC23766, similar to ZCL278, also increased the viability of the cells exposed to $\mathrm{NaAsO}_{2}$ significantly in dose-dependent manner. Based on the above results, $20 \mu \mathrm{M}$ ZCL278 and $50 \mu \mathrm{M}$ NSC23766 were selected for further study.

\section{Amelioration of $\mathrm{NaAsO}_{2}$-Induced Cytotoxicity by Inhibition of Cdc42 or Rac1 GTPases in} Rat CGNS

To understand whether Rho GTPases are involved in $\mathrm{NaAsO}_{2}$-induced cytotoxicity,

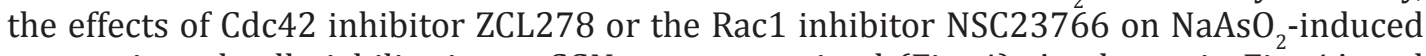
apoptosis and cell viability in rat CGNs were examined (Fig. 4). As shown in Fig. 4A and quantified in Fig. 4B, Cdc42 or Rac1 inhibition resulted in a significant decrease (56.91 $\pm 3.86 \%$, $53.24 \pm 8.17 \%$ ) of apoptotic cells in comparison with $\mathrm{NaAsO}_{2}$ exposure group $(67.77 \pm 5.37 \%)$. Furthermore, inhibition of Cdc42 or Rac1 ameliorated $\mathrm{NaAsO}_{2}$-induced inviability of rat 
Fig. 5. Knock-down of Ngb in rat CGNs. A. Ngb-siRNA and Negative-siRNA were transfected into rat CGNs. A representative qRT-PCR result shows that the expression level of Ngb mRNA decreased in Ngb-siRNA transfected rat CGNs compared with Control group. B. A representative Western blot analysis shows decreased expression of Ngb protein in Ngb-siRNA cells. All statistical results are expressed as means \pm SD from three independent experiments. ${ }^{*} P<0.05$, *** $P<0.001$ VS control group.

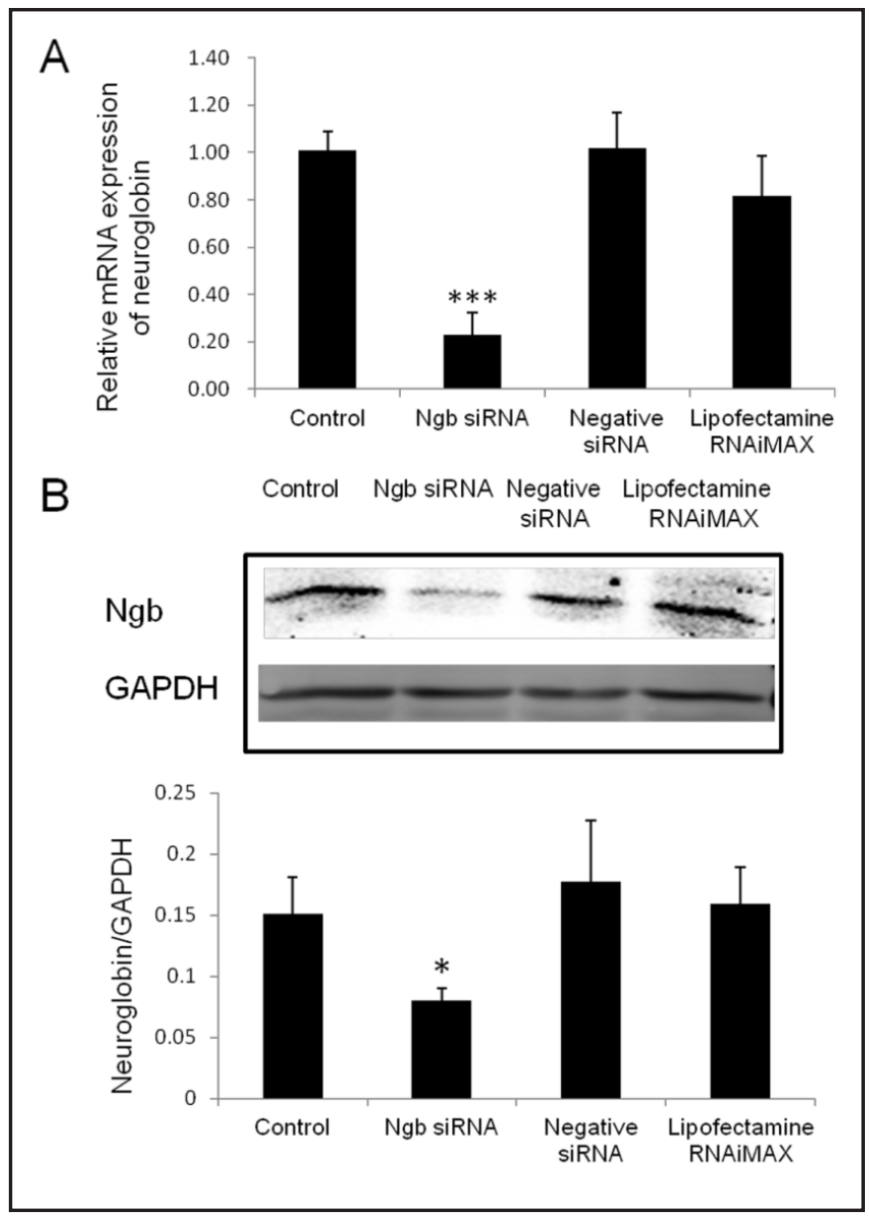

CGNs ( $p<0.05, p<0.01 \mathrm{VS} \mathrm{NaAsO} \mathrm{I}_{2}$ group; Fig. $4 \mathrm{C}$ ). These results indicate that $\mathrm{NaAsO}_{2}$ might induce neuron neurotoxicity by activating Cdc42 or Rac1.

Levels of Ngb mRNA and Protein expression by Treatment with Ngb-siRNA

An effective way of RNA interference, siRNA transfection, has been used for gene silencing and gene therapy applications [40]. Here, we used a siRNA system for knockdown of Ngb in rat CGNs. As shown in Fig. 5A, Ngb siRNA transfection resulted in significant decrease of Ngb mRNA levels in comparison with the untreated control $(p<0.001)$, negative siRNA $(p<0.001)$ and transfection reagent group $(p<0.001)$. Ngb protein levels in siRNA-transfected rat CGNs were lower than in control-transfected cells by western blot analysis (Fig. 5B). These results confirmed that the Ngb siRNA is specific and efficient, and Ngb mRNA and protein expressions were both remarkably knocked down in rat CGNs after siRNA transfection.

\section{Effect of Ngb siRNA on Arsenite-induced Neurotoxicity}

To investigate whether silencing Ngb expression could affect the vulnerability caused by $\mathrm{NaAsO}_{2}$, rat CGNs were transfected with or without $\mathrm{Ngb}$ siRNA for $48 \mathrm{~h}$, in the presence of $\mathrm{NaAsO}_{2}(10 \mu \mathrm{M}$ group) or same volume of PBS (Control group). Here, we evaluated the effect of Ngb siRNA on Arsenite-induced neurotoxicity in the cells using TUNEL and CCK-8 assays. Results showed apoptosis was obviously induced by $\mathrm{NaAsO}_{2}$ treatment in rat CGNs. Apoptotic cells were $20.61 \pm 6.35 \%, 67.77 \pm 5.37 \%, 24.75 \pm 4.80 \%$ and $80.67 \pm 5.39 \%$, respectively in the four groups (control, $\mathrm{NaAsO}_{2}$ treatment, $\mathrm{Ngb}$ siRNA, Ngb siRNA with $\mathrm{NaAsO}_{2}$ treatment group). Apoptotic cells increased significantly in Ngb siRNA-NaAsO $\mathrm{N}_{2}(p<0.001)$ and $\mathrm{NaAsO}_{2}$ $(p<0.001)$ exposure groups compared with the control group (Fig. 6A \& 6B). Meanwhile, Ngb siRNA transfection enhanced arsenite-induced apoptosis ( $p<0.01 \mathrm{VS} \mathrm{NaAsO}_{2}$ group; Fig. 6B). 


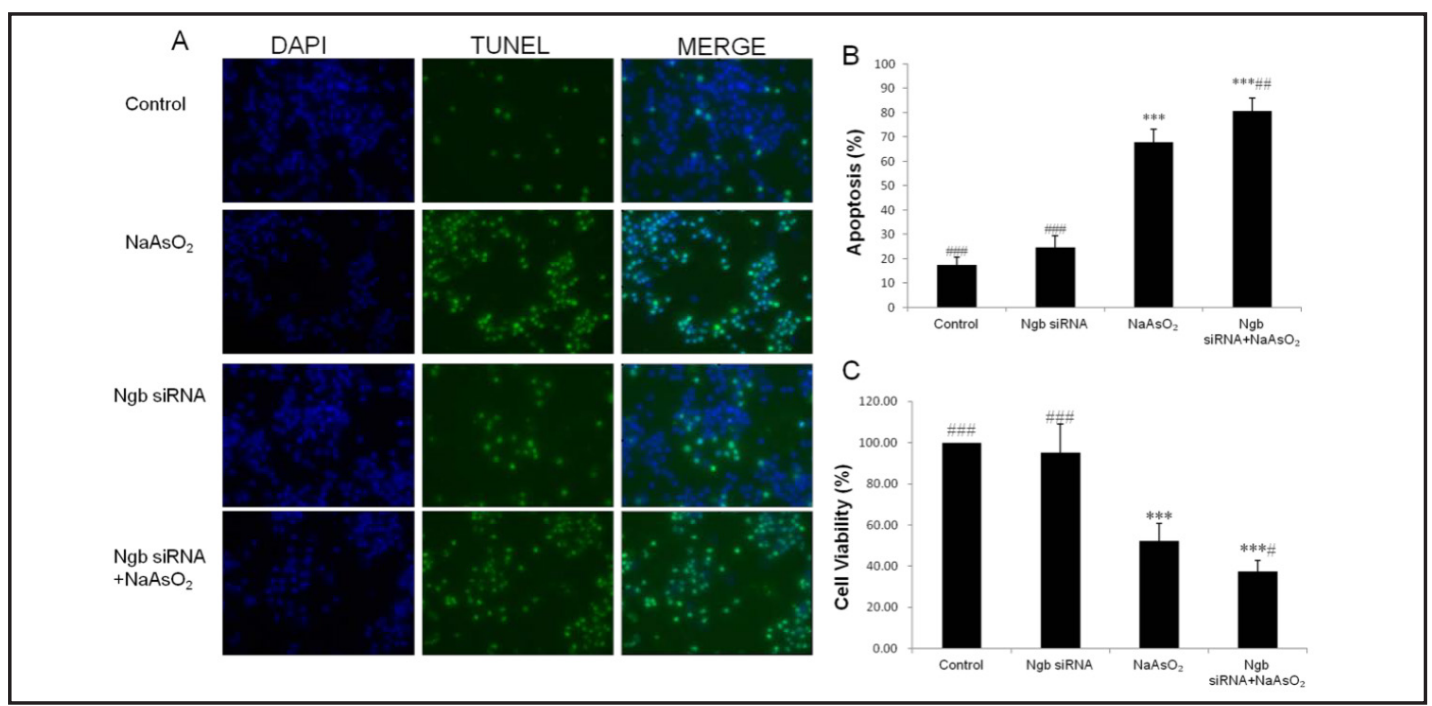

Fig. 6. Silencing of $\mathrm{Ngb}$ enhances cell death following $\mathrm{NaAsO}_{2}$ treatment. A. Ngb-siRNA and normal cells were exposed to $\mathrm{NaAsO}_{2}(0$ and $10 \mu \mathrm{M})$ for $24 \mathrm{~h}$. After treatment, specimens were labeled with TUNEL (green) and nuclei were stained blue with DAPI (fluorescence microscopy, original magnification $\times 400$ ). B. The graph indicates TUNEL-positive Ngb-siRNA transfected rat CGNs exposed to $\mathrm{NaAsO}_{2}(10 \mu \mathrm{M})$ increased significantly compared with those of normal cells. Ngb siRNA transfection enhanced arsenite-induced apoptosis compared with $\mathrm{NaAsO}_{2}$ treatment group. Data are expressed as mean $\pm \mathrm{SD}$ from at least 5 visual fields. C. Cell viability was measured using CCK-8 assay. Ngb siRNA transfection worsened arsenite-decreased viability of CGNs. ${ }^{* * *} P<0.001$ VS control, ${ }^{\#} P<0.05$, ${ }^{\# \#} P<0.01$, ${ }^{\# \# \# ~} P<0.001$ VS NaAsO ${ }_{2}$ treatment group.

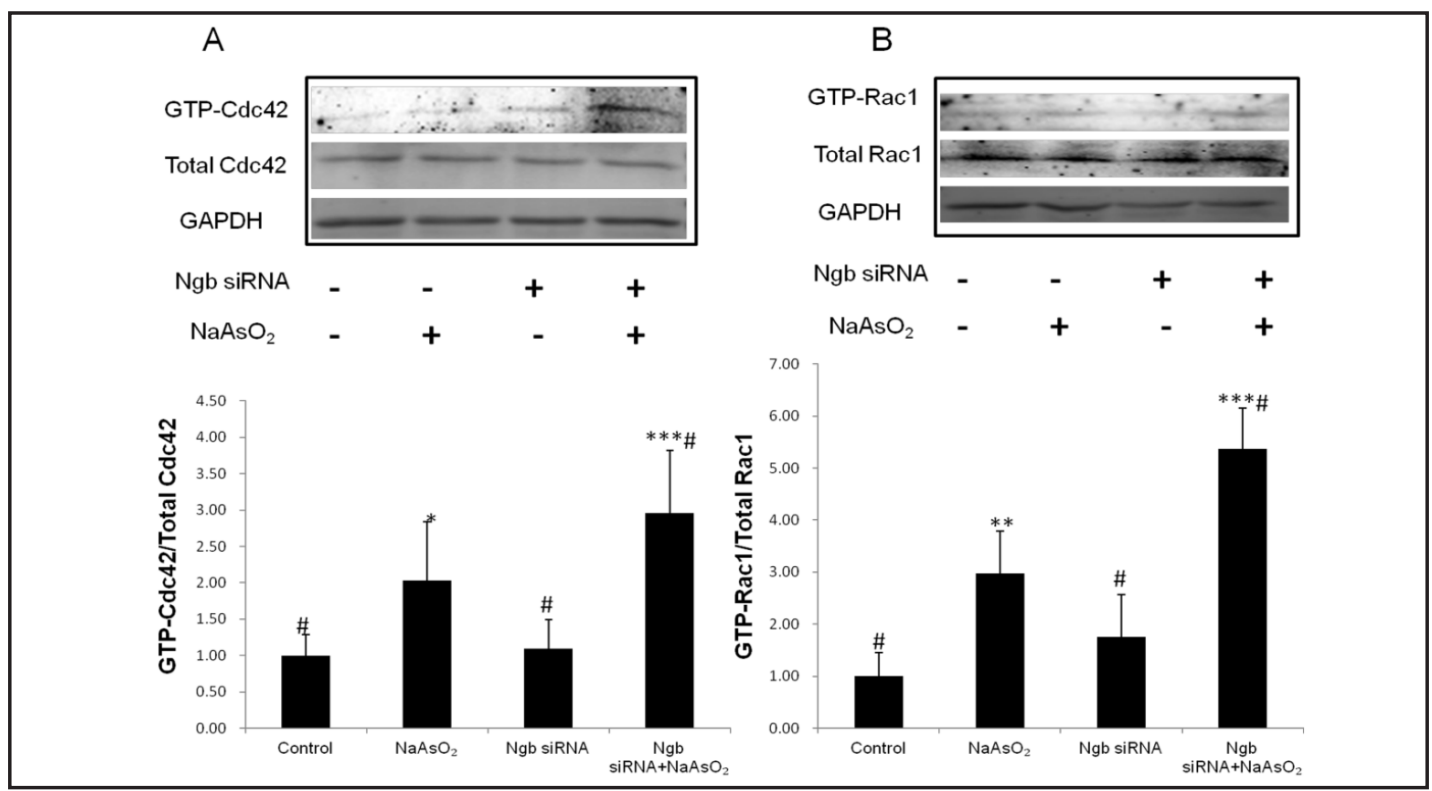

Fig. 7. Levels of activated Cdc42 and Rac1 in Ngb-siRNA transfected rat cerebellar granule neurons (CGNs). Representative images of western blot and corresponding densitometric quantification of the level of activated (A) Cdc42 and (B) Rac1 in Ngb-siRNA transfected rat CGNs. Ngb knockdown cells demonstrate higher levels of both activated Cdc42 and Rac1 than controls. All statistical results are expressed as means \pm SD from three independent experiments. ${ }^{*} P<0.05$, ${ }^{* *} P<0.01$, ${ }^{* * *} P<0.001 \mathrm{VS}$ control group, ${ }^{*} P<0.05 \mathrm{VS} \mathrm{NaAsO}_{2}$ treatment group.

Furthermore, transfection with Ngb siRNA potentiated arsenite-induced neuronal inviability $\left(p<0.05\right.$ VS $\mathrm{NaAsO}_{2}$ group; Fig. 6C). These data suggest that Ngb plays a neuroprotective role in the $\mathrm{NaAsO}_{2}$-induced neurotoxicity in primary cultured rat cerebellar granule neurons.

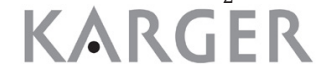




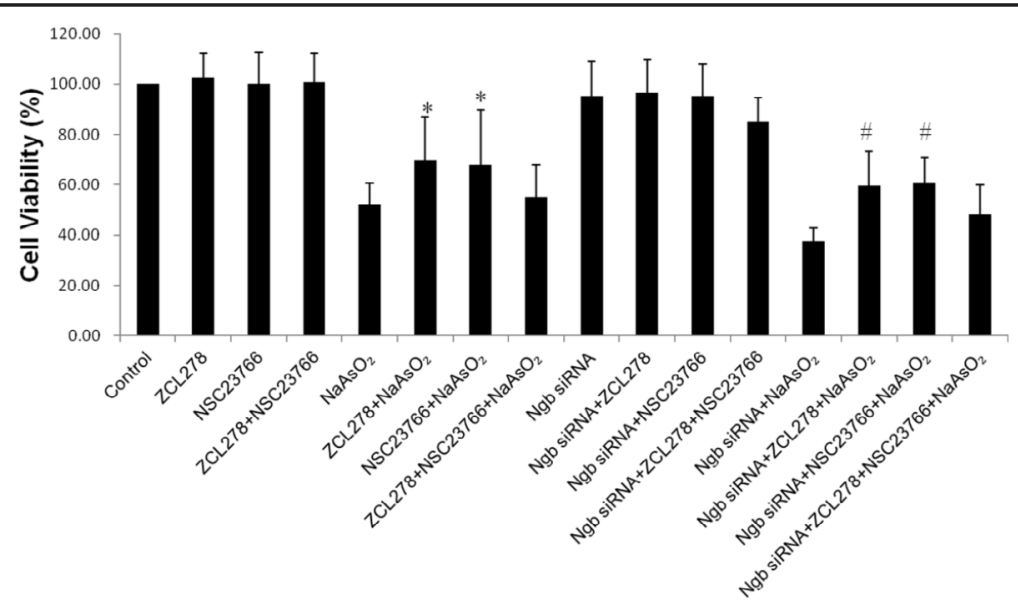

Fig. 8. Effects of ZCL278 and NSC23766 on viability of Ngb-siRNA transfected rat CGNs exposed to $\mathrm{NaAsO}_{2}$. ZCL278 and NSC23766 increased significantly cell viability compared with Ngb-siRNA transfected rat CGNs exposed to $\mathrm{NaAsO}_{2}$, respectively. All statistical results are expressed as means \pm SD from at least three independent experiments. ${ }^{*} P<0.05$ as compared with $\mathrm{NaAsO}_{2}$ treatment group alone, ${ }^{\#} P<0.05$ as compared with $\mathrm{Ngb}$-siRNA transfected $\mathrm{NaAsO}_{2}$ exposure group alone.

Effect of Ngb siRNA on Arsenite-induced Activation of Cdc42 or Rac1 GTPase

To examine the effects of $\mathrm{Ngb}$ siRNA on $\mathrm{NaAsO}_{2}$-induced activation of Cdc42 or Rac1, rates of Cdc42 or Rac1 activation were measured in the absence or presence of $\mathrm{NaAsO}_{2}(10$ $\mu \mathrm{M}$ ) with or without Ngb siRNA transfection. Results show that activation of Cdc42 did not change significantly in Ngb siRNA group in comparison with the untreated control. However, activation of $\mathrm{Cdc} 42$ increased significantly in $\mathrm{NaAsO}_{2}$ group ( $p<0.05$ vs control) and $\mathrm{Ngb}$ siRNA with $\mathrm{NaAsO}_{2}$ group ( $p<0.001$ vs control; Fig. 7A). Similar to Cdc42, activation of Rac1, given the same treatment, showed active Rac1 also increased significantly in $\mathrm{NaAsO}_{2}$ group ( $p<0.01$ vs control) and $\mathrm{Ngb}$ siRNA with $\mathrm{NaAsO}_{2}$ group ( $p<0.001$ vs control; Fig. $7 \mathrm{~B}$ ). Furthermore, Ngb siRNA transfection significantly ( $p<0.01$ vs $\mathrm{NaAsO}_{2}$ group) increased arsenite-elevated levels of Cdc42 or Rac1 activation.

Amelioration of $\mathrm{NaAsO}_{2}$-Induced Cytotoxicity by ZCL278 and NSC23766 in Ngb siRNASilenced Rat CGNs

To understand whether ZCL278 or NSC23766 ameliorate $\mathrm{NaAsO}_{2}$-induced cytotoxicity in untransfected or Ngb siRNA transfected cell, CCK-8 assay was used to assess cell viability. As shown in Fig. 8, ZCL278 or NSC23766 increased cell viability significantly both in untransfected and $\mathrm{Ngb}$-siRNA transfected rat CGNs exposed to $\mathrm{NaAsO}_{2}$, respectively $(p<0.05)$. When compared with $\mathrm{Ngb}$-siRNA transfected $\mathrm{NaAsO}_{2}$ exposure group alone, ZCL278 in combination with NSC23766 also increased cell viability in the cells, but there was no statistical significance ( $p>0.05)$. Similar to above result, both ZCL278 and NSC23766 in combination increased cell viability in untransfected group (Fig. 8), but there was also no statistical significance in comparison with $\mathrm{NaAsO}_{2}$ exposure group alone $(p>0.05)$. These results indicate that using ZCL278 or NSC23766 ameliorate significantly $\mathrm{NaAsO}_{2}$-induced cytotoxicity in untransfected or Ngb siRNA transfected rat CGNs.

\section{Discussion}

Arsenic is an environmental pollutant that affects various organs in human and experimental animals. Since cerebellum is an important target of As toxicity and Ngb is regarded as playing a GDI role to inactivate Rho GTPases, we carried out this study to 
investigate whether Ngb plays a role in the arsenite-induced cytotoxicity in rat CGNs by regulating activation of $\mathrm{Cdc} 42$ and Rac1 GTPases.

We used $10 \mu \mathrm{M} \mathrm{NaAsO}_{2}$ to treat these cells because in our previous findings, $10 \mu \mathrm{M}$ was half maximal (50\%) inhibitory concentration (IC50) of $\mathrm{NaAsO}_{2}$ against rat CGNs [8]. Furthermore, clinical studies have shown that the concentrations of arsenics (5.54-7.30 $\mu \mathrm{M})$ was the plasma levels of arsenics in patients treatment with arsenic trioxide [41]. Hence, 10 $\mu \mathrm{M} \mathrm{NaAsO} \mathrm{N}_{2}$ is the clinically relevant concentration.

Arsenic increased apoptosis and decreased cell viability, consistent with our previous studies and other studies $[8,9,42]$. Apoptosis is induced through many ways including the disequilibrium of apoptotic/anti-apoptotic $\mathrm{BCL}_{2}$ family members [43], reactive oxidative speciesgeneration [44], cytochromeC release, loss of mitochondrial transmembrane potential, inactivation of NF-kB [45, 46], activation of caspases [47], activation of MAPK pathways [48, 49], as well as activation of Rho GTPases pathway [9]. Among these mechanisms, the two best-characterized Rho family members Cdc42 and Rac1, have been found to play a critical role in regulating cellular processes, including cell proliferation, migration, differentiation, and apoptosis $[11,50]$. Rho GTPases activation has been investigated for their involvement in neurological disorders such as spinal cord injury, traumatic brain injury, stroke and Alzheimer's disease [18, 51-53]. Although many studies show Rho GTPases activation promotes cell survival, impairing of Rho GTPases inhibits growth of tumors by inducing apoptosis [54, 55], there are still opposite conclusions supporting that activation of Rho GTPase elicits cell apoptosis, consistent with our present study [56, 57]. In the present study, $\mathrm{NaAsO}_{2}$ induced Cdc42 or Rac1 activation. Cdc42 has been demonstrated to play an critical role in mediating apoptosis, whereas apoptosis-induction role of Rac1 was concluded differently in different studies [8, 58-63]. We used ZCL278, a Cdc42 inhibit, or NSC23766, a Rac1 inhibitor, to inhibit Cdc42 or Rac1 activity and detected apoptosis by TUNEL assay. Results indicate that both ZCL278 and NSC23766 reduced rat CGNs apoptosis induced by $\mathrm{NaAsO}_{2}$. This demonstrates that apoptosis caused by $\mathrm{NaAsO}_{2}$ exposure occurred at least partly due to Cdc42 or Rac1 activation in the present study. Furthermore, inhibition of Cdc42 or Rac1 increased the viability of the cells exposed to $\mathrm{NaAsO}_{2}$. These results indicate that $\mathrm{NaAsO}_{2}$ might induce cytotoxicity by activating Cdc42 and Rac1. Many reports showed that Rho GTPases also regulate the activities of a wide range of biochemical pathways such as the MAPKs. For instance, p38 kinases and ERKs can be activated in a Rho GTPases dependent manner [64, 65]. Interestingly, our previous studies have observed that p38 and ERK 1/2 activation were induced by $\mathrm{NaAsO}_{2}$ exposure in rat CGNs [8]. These findings indicate that Rho GTPase may either work alone by acting as signaling molecules or activate other signaling cascades to induce cytotoxicity in rat CGNs exposed to $\mathrm{NaAsO}_{2}$.

Damages activate the defense system. Arsenic-induced apoptosis and cell inviability trigger defense mechanisms to reduce the damages. $\mathrm{Ngb}$ is an endogenous neuroprotective molecule against damages [66]. However, the exact mechanism by which Ngb exert neuroprotective role still need to be clarified further. Ngb is regarded as a key mediator of protective effects in the brain including protection against oxidative stress, antiapoptosis, and control of inflammation [66]. In addition, Ngb could be involved in a signal transduction pathway, for example, by acting as a GDI for inhibiting GDP/GTP exchange, thus exert protective effects against cell death [67]. A number of studies point out a relation between Ngb and Rho family GTPases in several tissues [26, 28, 68]. For example, Cdc42 or Rac1 activity can be regulated though Rho GDIs which are traditionally thought to inhibit Rho GTPases activation [67, 69]. Our previous studies have observed that arsenite simultaneously induced Ngb upregulation and apoptosis. Higher Ngb expression may have decreased apoptosis induced by $\mathrm{NaAsO}_{2}$ in rat CGNs. Many studies have employed Ngb overexpression to confer an enhanced neuroprotection [24]. In contrast, we employed Ngb siRNA transfection and found that $\mathrm{Ngb}$ silencing significantly exacerbated $\mathrm{NaAsO}_{2}$-induced cytotoxicity in rat CGNs, supporting a neuroprotective role of $\mathrm{Ngb}$ in arsenite-induced injury of neurons. To clarify the relationship between Ngb and Rho-like Cdc42 or Rac1 GTPase, we used $\mathrm{Ngb}$ siRNA to inhibit $\mathrm{Ngb}$ followed by $\mathrm{NaAsO}_{2}$ exposure and detect the activation of 
Cdc42 or Rac1 by pull-down assay. Results show that Ngb knockdown significantly increased arsenite-elevated levels of Cdc42 or Rac1 activation. To understand whether inhibition of Cdc42 or Rac1 GTPases ameliorate $\mathrm{NaAsO}_{2}$-induced cytotoxicity in Ngb siRNA transfected rat CGNs exposed to $\mathrm{NaAsO}_{2}$, we used ZCL278 or NSC23766 to inhibit Cdc42 or Rac1 and detect cell viability by CCK-8 assay. Results confirmed that using ZCL278 or NSC23766 decrease $\mathrm{NaAsO}_{2}$-induced injury in Ngb knockdown rat CGNs. These data suggest that Ngb impairs Rho GTPases pathway in the cells exposed to arsenite, providing an explanation of $\mathrm{Ngb}$ action in the protection of nerve cells from apoptosis and cytotoxicity [28].

In summary, $\mathrm{NaAsO}_{2}$ induced cell cytotoxicity, activated Cdc42 and Rac1 GTPases, and inhibition of Cdc42 or Rac1 decreased $\mathrm{NaAsO}_{2}$-induced cytotoxicity in rat CGNs. Also, Ngb knockdown significantly increased apoptosis and cell death, increased Cdc42 or Rac1 activation in rat CGNs exposed to $\mathrm{NaAsO}_{2}$. It can be deduced $\mathrm{Ngb}$ plays a protective role against cytotoxicity by inhibition of Cdc42 and Rac1 GTPases in rat CGNs exposed to $\mathrm{NaAsO}_{2}$. Our research provides insight into possible mechanisms of Ngb neuroprotection, and may provide therapeutic implication at $\mathrm{NaAsO}_{2}$-induced injury of neurons.

\section{Abbreviations}

$\mathrm{Ngb}$ (neuroglobin); $\mathrm{NaAsO}_{2}$ sodium arsenite); CGNs (cerebellar granule neurons); Rho GTPases (Rho guanosine triphosphatases); GDI (guanine nucleotide dissociation inhibitior).

\section{Acknowledgements}

This work was supported by the National Natural Science Foundation of China (Grant No. 81102082 and Grant No. 81273013).

\section{Disclosure Statement}

The authors declare no conflicts of interest.

\section{Reference}

1 Tapio S, Grosche B: Arsenic in the aetiology of cancer. Mutat Res 2006;612:215-246.

2 Naujokas MF, Anderson B, Ahsan H, Aposhian HV, Graziano JH, Thompson C, Suk WA: The broad scope of health effects from chronic arsenic exposure: Update on a worldwide public health problem. Environ Health Perspect 2013;121:295-302.

3 Ivanov VN, Hei TK: Induction of apoptotic death and retardation of neuronal differentiation of human neural stem cells by sodium arsenite treatment. Exp Cell Res 2013;319:875-887.

4 Negishi T, Takahashi M, Matsunaga Y, Hirano S, Tashiro T: Diphenylarsinic acid increased the synthesis and release of neuroactive and vasoactive peptides in rat cerebellar astrocytes. J Neuropathol Exp Neurol 2012;71:468-479.

5 Negishi T, Matsunaga Y, Kobayashi Y, Hirano S, Tashiro T: Developmental subchronic exposure to diphenylarsinic acid induced increased exploratory behavior, impaired learning behavior, and decreased cerebellar glutathione concentration in rats. Toxicol Sci 2013;136:478-486.

6 Ding X, Su Q Jiang M, Xie H, Cong J, Wang L: Arsenic affects on cerebellar development of mice. Toxicol Mech Methods 2013;23:672-677.

7 Wang J, Zhang W, Sun D, Song L, Li Y, Xu C: Analysis of neuroglobin mrna expression in rat brain due to arsenite-induced oxidative stress. Environ Toxicol 2012;27:503-509. 


\section{Cellular Physiology Cell Physiol Biochem 2015;36:1613-1627 \begin{tabular}{ll|l} 
and Biochemistry & $\begin{array}{l}\text { DOI: 10.1159/000430323 } \\
\text { Published online: July 10, } 2015\end{array}$ & $\begin{array}{l}\text { O 2 2015 S. Karger AG, Basel } \\
\text { www.karger.com/cpb }\end{array}$ \\
\cline { 2 - 3 }
\end{tabular}}

8 Liu X, Gao Y, Yao H, Zhou L, Pei J, Sun L, Wang J, Sun D: P38 and extracellular signal-regulated kinases activations have opposite effects on primary-cultured rat cerebellar granule neurons exposed to sodium arsenite. J Biochem Mol Toxicol 2014;28:143-148.

9 Yih LH, Wu YC, Hsu NC, Kuo HH: Arsenic trioxide induces abnormal mitotic spindles through a pip4kiigamma/rho pathway. Toxicol Sci 2012;128:115-125.

10 Namgung U, Xia Z: Arsenic induces apoptosis in rat cerebellar neurons via activation of jnk3 and p38 map kinases. Toxicol Appl Pharmacol 2001;174:130-138.

11 Etienne-Manneville S, Hall A: Rho gtpases in cell biology. Nature 2002;420:629-635.

12 Pang X, Yi T, Yi Z, Cho SG, Qu W, Pinkaew D, Fujise K, Liu M: Morelloflavone, a biflavonoid, inhibits tumor angiogenesis by targeting rho gtpases and extracellular signal-regulated kinase signaling pathways. Cancer Res 2009;69:518-525.

13 Burridge K, Wennerberg K: Rho and rac take center stage. Cell 2004;116:167-179.

14 Stengel K, Zheng Y: Cdc42 in oncogenic transformation, invasion, and tumorigenesis. Cell Signal 2011;23:1415-1423.

15 Friesland A, Zhao Y, Chen YH, Wang L, Zhou H, Lu Q: Small molecule targeting cdc42-intersectin interaction disrupts golgi organization and suppresses cell motility. Proc Natl Acad Sci U S A 2013;110:1261-1266.

16 Hall A: Rho gtpases and the actin cytoskeleton. Science 1998;279:509-514.

17 Yoshida T, Zhang Y, Rivera Rosado LA, Chen J, Khan T, Moon SY, Zhang B: Blockade of rac1 activity induces g1 cell cycle arrest or apoptosis in breast cancer cells through downregulation of cyclin d1, survivin, and x-linked inhibitor of apoptosis protein. Mol Cancer Ther 2010;9:1657-1668.

18 Dubreuil CI, Winton MJ, McKerracher L: Rho activation patterns after spinal cord injury and the role of activated rho in apoptosis in the central nervous system. J Cell Biol 2003;162:233-243.

19 Ellenbroek SI, Collard JG: Rho gtpases: Functions and association with cancer. Clin Exp Metastasis 2007;24:657-672.

20 Bazenet CE, Mota MA, Rubin LL: The small gtp-binding protein cdc42 is required for nerve growth factor withdrawal-induced neuronal death. Proc Natl Acad Sci U S A 1998;95:3984-3989.

21 Lehmann M, Fournier A, Selles-Navarro I, Dergham P, Sebok A, Leclerc N, Tigyi G, McKerracher L: Inactivation of rho signaling pathway promotes cns axon regeneration. J Neurosci 1999;19:7537-7547.

22 Burmester T, Weich B, Reinhardt S, Hankeln T: A vertebrate globin expressed in the brain. Nature 2000;407:520-523.

23 Li RC, Morris MW, Lee SK, Pouranfar F, Wang Y, Gozal D: Neuroglobin protects pc12 cells against oxidative stress. Brain Res 2008;1190:159-166.

24 Wang X, Liu J, Zhu H, Tejima E, Tsuji K, Murata Y, Atochin DN, Huang PL, Zhang C, Lo EH: Effects of neuroglobin overexpression on acute brain injury and long-term outcomes after focal cerebral ischemia. Stroke 2008;39:1869-1874.

25 Li SQ, Li WB, Zhang M, Wu YZ, Hu YY: The role of neuroglobin in the neuroprotection of limb ischemic preconditioning in rats. Mol Neurobiol 2013;47:197-208.

26 Wakasugi K, Nakano T, Morishima I: Oxidized human neuroglobin acts as a heterotrimeric galpha protein guanine nucleotide dissociation inhibitor. J Biol Chem 2003;278:36505-36512.

27 Schwindinger WF, Robishaw JD: Heterotrimeric g-protein betagamma-dimers in growth and differentiation. Oncogene 2001;20:1653-1660.

28 Yu Z, Fan X, Lo EH, Wang X: Neuroprotective roles and mechanisms of neuroglobin. Neurol Res 2009;31:122-127.

29 Liu X, Gao Y, Yao H, Zhou L, Sun D, Wang J: Neuroglobin involvement in the course of arsenic toxicity in rat cerebellar granule neurons. Biol Trace Elem Res 2013;155:439-446.

30 Lee HY, Greene LA, Mason CA, Manzini MC: Isolation and culture of post-natal mouse cerebellar granule neuron progenitor cells and neurons. J Vis Exp 2009

31 Ishiyama M, Tominaga H, Shiga M, Sasamoto K, Ohkura Y, Ueno K: A combined assay of cell viability and in vitro cytotoxicity with a highly water-soluble tetrazolium salt, neutral red and crystal violet. Biol Pharm Bull 1996;19:1518-1520.

32 Hundahl C, Kelsen J, Kjaer K, Ronn LC, Weber RE, Geuens E, Hay-Schmidt A, Nyengaard JR: Does neuroglobin protect neurons from ischemic insult? A quantitative investigation of neuroglobin expression following transient mcao in spontaneously hypertensive rats. Brain Res 2006;1085:19-27. 
33 Livak KJ, Schmittgen TD: Analysis of relative gene expression data using real-time quantitative pcr and the 2(-delta delta $c(t))$ method. Methods 2001;25:402-408.

34 Pfaffl MW: A new mathematical model for relative quantification in real-time rt-pcr. Nucleic Acids Res 2001;29:e45.

35 Sander EE, Jean P, van Delft S, van der Kammen RA, Collard JG: Rac downregulates rho activity reciprocal balance between both gtpases determines cellular morphology and migratory behavior. The Journal of cell biology 1999;147:1009-1022.

36 Aghajanian A, Wittchen ES, Campbell SL, Burridge K: Direct activation of rhoa by reactive oxygen species requires a redox-sensitive motif. PloS one 2009;4:e8045.

37 Kroemer G, Galluzzi L, Vandenabeele P, Abrams J, Alnemri ES, Baehrecke EH, Blagosklonny MV, El-Deiry WS, Golstein P, Green DR, Hengartner M, Knight RA, Kumar S, Lipton SA, Malorni W, Nunez G, Peter ME, Tschopp J, Yuan J, Piacentini M, Zhivotovsky B, Melino G: Classification of cell death: Recommendations of the nomenclature committee on cell death 2009. Cell Death Differ 2009;16:3-11.

38 Potin S, Bertoglio J, Breard J: Involvement of a rho-rock-jnk pathway in arsenic trioxide-induced apoptosis in chronic myelogenous leukemia cells. FEBS Lett 2007;581:118-124.

39 Verma A, Ihler GM: Activation of rac, cdc42 and other downstream signalling molecules by bartonella bacilliformis during entry into human endothelial cells. Cell Microbiol 2002;4:557-569.

40 Yang WQ, Zhang Y: Rnai-mediated gene silencing in cancer therapy. Expert Opin Biol Ther 2012;12:14951504.

41 Shen ZX, Chen GQ, Ni JH, Li XS, Xiong SM, Qiu QY, Zhu J, Tang W, Sun GL, Yang KQ Chen Y, Zhou L, Fang ZW, Wang YT, Ma J, Zhang P, Zhang TD, Chen SJ, Chen Z, Wang ZY: Use of arsenic trioxide (as2o3) in the treatment of acute promyelocytic leukemia (apl): Ii. Clinical efficacy and pharmacokinetics in relapsed patients. Blood 1997;89:3354-3360.

42 Liang H, Li X, Wang L, Yu S, Xu Z, Gu Y, Pan Z, Li T, Hu M, Cui H, Liu X, Zhang Y, Xu C, Guo R, Lu Y, Yang B, Shan H: Micrornas contribute to promyelocyte apoptosis in as2o3-treated apl cells. Cell Physiol Biochem 2013;32:1818-1829.

43 Scholz C, Richter A, Lehmann M, Schulze-Osthoff K, Dorken B, Daniel PT: Arsenic trioxide induces regulated, death receptor-independent cell death through a bcl-2-controlled pathway. Oncogene 2005;24:7031-7042.

44 Ho SY, Wu WJ, Chiu HW, Chen YA, Ho YS, Guo HR, Wang YJ: Arsenic trioxide and radiation enhance apoptotic effects in hl-60 cells through increased ros generation and regulation of jnk and p38 mapk signaling pathways. Chem Biol Interact 2011;193:162-171.

45 Mathas S, Lietz A, Janz M, Hinz M, Jundt F, Scheidereit C, Bommert K, Dorken B: Inhibition of nf-kappab essentially contributes to arsenic-induced apoptosis. Blood 2003;102:1028-1034.

46 Yedjou C, Tchounwou P, Jenkins J, McMurray R: Basic mechanisms of arsenic trioxide (ato)-induced apoptosis in human leukemia (hl-60) cells. J Hematol Oncol 2010;3:28.

47 Huang XJ, Wiernik PH, Klein RS, Gallagher RE: Arsenic trioxide induces apoptosis of myeloid leukemia cells by activation of caspases. Med Oncol 1999;16:58-64.

48 Liu Y, Hock JM, Sullivan C, Fang G, Cox AJ, Davis KT, Davis BH, Li X: Activation of the p38 mapk/akt/erk1/2 signal pathways is required for the protein stabilization of cdc6 and cyclin $\mathrm{d} 1 \mathrm{in}$ low-dose arsenite-induced cell proliferation. J Cell Biochem 2010;111:1546-1555.

49 Fan Y, Wang C, Zhang Y, Hang P, Liu Y, Pan Z, Wang N, Du Z: Genistein ameliorates adverse cardiac effects induced by arsenic trioxide through preventing cardiomyocytes apoptosis. Cell Physiol Biochem 2013;31:80-91.

50 Jaffe AB, Hall A: Rho gtpases: Biochemistry and biology. Annu Rev Cell Dev Biol 2005;21:247-269.

51 Lu Q Longo FM, Zhou H, Massa SM, Chen YH: Signaling through rho gtpase pathway as viable drug target. Curr Med Chem 2009;16:1355-1365.

52 Mueller BK, Mack H, Teusch N: Rho kinase, a promising drug target for neurological disorders. Nat Rev Drug Discov 2005;4:387-398.

53 Dubreuil CI, Marklund N, Deschamps K, McIntosh TK, McKerracher L: Activation of rho after traumatic brain injury and seizure in rats. Exp Neurol 2006;198:361-369.

54 Zins K, Lucas T, Reichl P, Abraham D, Aharinejad S: A rac1/cdc42 gtpase-specific small molecule inhibitor suppresses growth of primary human prostate cancer xenografts and prolongs survival in mice. PloS one 2013;8:e74924. 


\section{Cellular Physiology Cell Physiol Biochem 2015;36:1613-1627 \begin{tabular}{l|l} 
DOI: 10.1159/000430323 & $\begin{array}{l}\text { O 2015 S. Karger AG, Basel } \\
\text { www.karger.com/cpb }\end{array}$ \\
\hline
\end{tabular}}

55 Fujimura M, Usuki F, Sawada M, Rostene W, Godefroy D, Takashima A: Methylmercury exposure downregulates the expression of racl and leads to neuritic degeneration and ultimately apoptosis in cerebrocortical neurons. Neurotoxicology 2009;30:16-22.

56 Semenova MM, Maki-Hokkonen AM, Cao J, Komarovski V, Forsberg KM, Koistinaho M, Coffey ET, Courtney MJ: Rho mediates calcium-dependent activation of p38alpha and subsequent excitotoxic cell death. Nat Neurosci 2007;10:436-443.

57 Zhu Y, Casey PJ, Kumar AP, Pervaiz S: Deciphering the signaling networks underlying simvastatin-induced apoptosis in human cancer cells: Evidence for non-canonical activation of rhoa and rac1 gtpases. Cell Death Dis 2013;4:e568.

58 Jin Y, Liu Y, Lin Q Li J, Druso JE, Antonyak MA, Meininger CJ, Zhang SL, Dostal DE, Guan JL, Cerione RA, Peng $\mathrm{X}$ : Deletion of cdc42 enhances adam17-mediated vascular endothelial growth factor receptor 2 shedding and impairs vascular endothelial cell survival and vasculogenesis. Mol Cell Biol 2013;33:4181-4197.

59 Kissil JL, Walmsley MJ, Hanlon L, Haigis KM, Bender Kim CF, Sweet-Cordero A, Eckman MS, Tuveson DA, Capobianco AJ, Tybulewicz VL, Jacks T: Requirement for rac1 in a k-ras induced lung cancer in the mouse. Cancer Res 2007;67:8089-8094.

60 Liu SY, Yen CY, Yang SC, Chiang WF, Chang KW: Overexpression of rac-1 small gtpase binding protein in oral squamous cell carcinoma. J Oral Maxillofac Surg 2004;62:702-707.

61 Shen E, Li Y, Shan L, Zhu H, Feng Q Arnold JM, Peng T: Rac1 is required for cardiomyocyte apoptosis during hyperglycemia. Diabetes 2009;58:2386-2395.

62 Sanno H, Shen X, Kuru N, Bormuth I, Bobsin K, Gardner HA, Komljenovic D, Tarabykin V, Erzurumlu RS, Tucker KL: Control of postnatal apoptosis in the neocortex by rhoa-subfamily gtpases determines neuronal density. J Neurosci 2010;30:4221-4231.

63 Li F, Jiang Q, Shi KJ, Luo H, Yang Y, Xu CM: Rhoa modulates functional and physical interaction between rock1 and erk1/2 in selenite-induced apoptosis of leukaemia cells. Cell Death Dis 2013;4:e708.

64 Li W, Chong H, Guan KL: Function of the rho family gtpases in ras-stimulated raf activation. J Biol Chem 2001;276:34728-34737.

65 Arai A, Kanda E, Miura 0: Rac is activated by erythropoietin or interleukin-3 and is involved in activation of the erk signaling pathway. Oncogene 2002;21:2641-2651.

66 Li W, Wu Y, Ren C, Lu Y, Gao Y, Zheng X, Zhang C: The activity of recombinant human neuroglobin as an antioxidant and free radical scavenger. Proteins 2011;79:115-125.

67 Khan AA, Mao XO, Banwait S, DerMardirossian CM, Bokoch GM, Jin K, Greenberg DA: Regulation of hypoxic neuronal death signaling by neuroglobin. FASEB J 2008;22:1737-1747.

68 Kitatsuji C, Kurogochi M, Nishimura S, Ishimori K, Wakasugi K: Molecular basis of guanine nucleotide dissociation inhibitor activity of human neuroglobin by chemical cross-linking and mass spectrometry. J Mol Biol 2007;368:150-160.

69 Wang Z, Thurmond DC: Differential phosphorylation of rhogdi mediates the distinct cycling of cdc42 and rac1 to regulate second-phase insulin secretion. J Biol Chem 2010;285:6186-6197. 